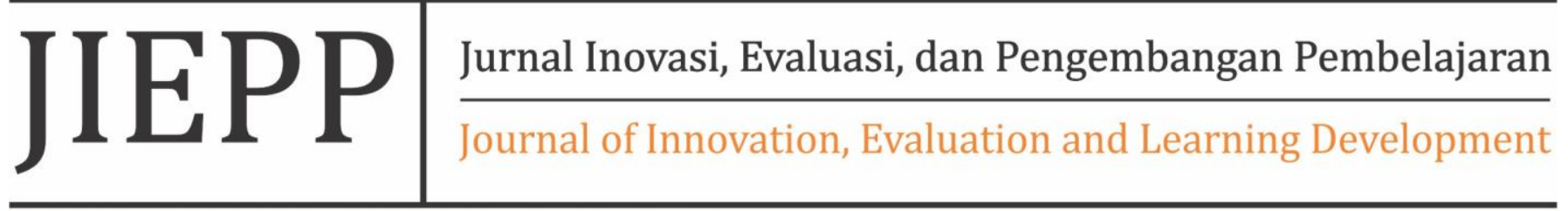

\section{Perbandingan Hasil Belajar Matematika Siswa yang diajar dengan Model Pembelajaran Possing Problem Berkelompok dan Metode Ceramah}

\author{
Asmedy \\ Program studi Pendidikan Teknologi Informasi, STKIP Yapis Dompu \\ E-mail: asmedy.ainara@gmail.com
}

Article History: Received: 2021-10-12 || Revised: 2021-11-27 || Published: 2021-12-30

Sejarah Artikel : Diterima: 2021-10-12 || Direvisi: 2021-11-27 || Dipublikasi: 2021-12-30

\begin{abstract}
Research has been carried out with the title of differences in student learning outcomes in mathematics who are taught using the group problem-posing learning model and the lecture method. The purpose of this study is to find out whether there are differences in the mathematics learning outcomes of class VIII students of SMP Negeri 3 Donggo in odd semesters on the subject of linear equation systems in the 2021/2022 school year who are taught using the group possing problem learning model and the lecture method. It is an experimental research. The results of the assessment that $t$ arithmetic is greater than $t$ table with a significance level of $5 \%$ so that it can be concluded that Ho is rejected and Ha is accepted. The hypothesis reads "There are differences in the mathematics learning outcomes of class VIII students of SMP Negeri 3 Donggo in odd semesters on the subject of linear equation systems for the 2021/2022 school year who are taught using the group problem-posing learning model and the lecture method".
\end{abstract}

Keywords: Learning Outcomes, Mathematics, Possing Problems, Lectures.

\begin{abstract}
Abstrak
Telah dilakukan penelitian dengan judul perbedaan hasil belajar matematika siswa yang diajar dengan model pembelajaran possing problem berkelompok dan metode ceramah. Tujuan penelitian ini yakni untuk mengetahui apakah terdapat perbedaan hasil belajar matematika siswa kelas VIII SMP Negeri 3 Donggo semester ganjil pokok bahasan sistem persamaan linier tahun pelajaran 2021/2022 yang diajar menggunakan model pembelajaran possing problem berkelompok dan metode ceramah. Merupakan penelitian eksperimen. Hasil penilaian bahwa $t$ hitung lebih besar daripada $t$ tabel dengan taraf signifikansi 5\% sehingga dapat ditarik kesimpulan bahwa Ho ditolak dan Ha diterima. Hipotesisnya berbunyi "Terdapat perbedaan hasil belajar matematika siswa kelas VIII SMP Negeri 3 Donggo semester ganjil pokok bahasan sistem persamaan linier tahun pelajaran 2021/2022 yang diajar menggunakan model pembelajaran possing problem berkelompok dan metode ceramah".
\end{abstract}

Kata kunci: Hasil Belajar, Matematika, Possing Problem, Ceramah.

\section{PENDAHULUAN}

Perkembangan zaman sebagai akibat dari perkembangan ilmu pengetahuan dan teknologi harus disejajarkan dengan penyediaan sumber daya manusia yang berkualitas. Pendidikan menjadi pioner utama dalam rangka penyiapan sumber daya manusia yang berkualitas. Pendidikan merupakan salah satu aspek pembangunan yang sekaligus merupakan syarat mutlak untuk mewujudkan pembangunan nasional. Tilaar (dalam Faturrahman, 2012:16), selain itu perkembangan IPTEK sebagai akibat dari terjadinya globalisasi di hampir seluruh aspek kehidupan masyarakat, seharusnya menjadi dasar pijak keharusan untuk memikirkan dan mereformasi ulang tentang sistem dan pola pelaksanaan pendidikan. Bagaimanapun juga sebuah sistem pada suatu masa akan sangat sesuai tetapi tidak dapat dipungkiri bahwa sistem tersebut akan sangat tertinggal dan tidak memenuhi tuntutan perubahan yang terjadi. (Faturrahman, 2012:17). 
Tentu tidak dapat dipisah dari berbagai faktor yang terkait baik secara langsung maupun tidak langsung. Beberapa program pemerintah telah diupayakan sebagai sebuah alternatif dalam rangka menyiapkan dan meningkatkan mutu pendidikan. Sebagai contoh adalah dari program wajib belajar 6 tahun menjadi wajib belajar 9 tahun. Namun hal ini hanya dapat meningkatkan pendidikan dari aspek kuantitas akan tetapi belum menyentuh aspek kualitas dari out put Pendidikan, dunia pendidikan Indonesia tidak sepi dari kritikan dan teguran. Selain pelaksanaan kebijakan kurukulum pendidikan yang tidak biasa, mahalnya biaya pendidikan sampai buruknya kualitas pendidikan Indonesia yang masih menjadi pembicaraan seluruh warga negara Indonesia. Pendidikan yang semula dimaksudkan untuk mencerdaskan kehidupan bangsa dan negara kini melenceng dan terbukti lahan pendidikan dijadikan sebagai lahan bisnis untuk mencari keuntungan. (Faturrahman, 2012:33).

Mutu pendidikan di Indonesia dapat disimak dari hasil studi internasional dimana penguasaan siswa SMP pada mata pelajaran Matematika berada pada peringkat 32 dan 34 di bawah Malaysia. Hasil Ujian Akhir Nasional SMP dengan batas nilai kelulusan rata-rata 6,0 secara nasional belum meluluskan $100 \%$ bahkan ada sekolah yang 30\% siswanya tidak lulus. Kita patut mensyukuri bahwa secara nasional angka tidak lulus relatif kecil. Namun demikian kita juga seharusnya tercambuk untuk bekerja lebih keras lagi karena batas 6,0 bukanlah tingkat penguasaan atau ketuntasan yang aman, dengan kata lain angka tersebut belum kompetitif. Relevansi pendidikan dengan kehidupan juga masih rendah seperti masih banyak lulusan yang menganggur Jihad (2008:64).

Padahal dalam KTSP kurikulum dikembangkan berdasarkan prinsip-bahwa peserta didik memiliki posisi sentral untuk mengembangkan kompetensinya agar menjadi manusia yang beriman dan bertaqwa kepada Tuhan YME, berakhlak mulia, sehat, berilmu, cakap, kreatif, mandiri dan menjadi warga Negara yanag demokratis serta bertanggung jawab. Untuk mendukung pencapaian tujuan tersebut pengembangan kompetensi peserta didik disesuaikan dengan potensi, perkembangan, kebutuhan, dan kepentingan peserta didik serta tuntutan lingkungan. Memiliki posisi sentral berarti kegiatan pembelajaran berpusat pada peserta didik Jihad (2008:104), berdasarkan penjabaran tersebut di atas salah satu model pembelajaran yang cocok untuk diterapkan dan berpusat pada peserta didik di kelas VIII SMP yaitu pembelajaran Possing Problem. Pembelajaran Possing Problem merupakan pembelajaran yang mengharuskan siswa menyusun pertanyaan sendiri atau memecahkan soal menjadi pertanyaan-pertanyaan sederhana yang mengacu pada penyelesaian soal tersebut (Thobroni, 2011: 350).

Melalui pembelajaran Possing Problem ini dapat memberi penguatan terhadap konsep yang diterima atau memperkaya konsep-konsep dasar. Kemudian juga dapat melatih siswa meningkatkan kemampuannya dalam belajar. Serta membiasakan siswa untuk melakukan investigasi dan penemuan yang pada dasarnya merupakan pemecahan masalah (Thobroni, 2011: 352), berdasarkan latar belakang di atas maka judul penelitian ini yaitu "perbedaan hasil belajar matematika siswa yang diajar dengan model pembelajaran possing problem berkelompok dan metode ceramah pada siswa kelas VIII SMP Negeri 3 Donggo semester ganjil pokok bahasan sistem persamaan linier tahun pelajaran 2021/2022".

\section{METODE PENELITIAN}

A. Jenis Penelitian

Jenis penelitian yang digunakan adalah penelitian eksperimen yaitu penelitian yang digunakan untuk membandingkan penggunaan suatu model pembelajaran tertentu terhadap model pembelaaran yang umum dan biasa dilakukan, dalam kondisi terkendali, tergolong dalam penelitian komparatif, Dimana penelitian ini menggunkan pendekatan kuantitatif. Nantinya peneliti memberikan perlakuan pada dua kelas, kelas pertama yaitu kelas eksperimen, di kelas ini akan diberi perlakuan yaitu diajar dengan pembelajaran Possing Problem dan kelas kedua yaitu kelas kontrol, kelas ini akan diberi perlakuan yaitu diajar menggunakan metode ceramah, dengan maksud untuk mengetahui bagaimana hasil belajar siswa pada kedua kelas, desain penelitian merupakan strategi untuk mengatur jalannya penelitian agar peneliti memperoleh data valid sesuai karakteristik variabel dan tujuan. Desain penelitian yang digunakan yaitu True 
Eksperimen Design dengan bentuk Pretest-Posttest Control Groupe Design. Adapun pola dari desain ini adalah sebagai berikut (Arikunto, 2006):

\begin{tabular}{|llll|}
\hline $\mathbf{E}$ & $\mathbf{O}_{1}$ & $\mathrm{X}$ & $\mathbf{O}_{2}$ \\
\cline { 2 - 4 } $\mathrm{K}$ & $\mathbf{O}_{3}$ & $\mathbf{X}$ & $\mathbf{O}_{4}$ \\
\hline
\end{tabular}

Keterangan:

E : Kelas Eksperimen

$\mathrm{K}$ : Kelas Kontrol

$\mathrm{O}_{1}$ : Kelas Eksperimen sebelum diberi perlakuan

$\mathrm{O}_{2}$ : Kelas Eksperimen setelah diberi perlakuan

$\mathrm{X}$ : Perlakuan yaitu pembelajaran possing problem

$\mathrm{O}_{3}$ : Kelas Kotrol sebelum diberi perlakuan

$\mathrm{O}_{4}$ : Kelas Kontrol setelah diberi perlakuan

Prosedur penelitian merupakan langkah yang akan disusun peneliti berdasarkan jenis penelitian yang dilakukan dalam rangka mengetahuai sejauh mana hasil belajar antara kelas eksperimen dengan kelas kontrol. Berdasarkan hal tersebut untuk lebih jelasnya tentang berbagai tindakan yang nantinya dilakukan akan dijelaskan langkah-langkah dalam penelitian ini. Di awal melakukan kegiatan pra penelitian meliputi meminta ijin pada sekolah untuk diadakan penelitian, juga meminta ijin pada sekolah lain untuk mengadakan try out dalam rangka menguji validitas dan reliabilitas soal-soal yang akan di gunakan dalam penelitian, mempersiapkan segala instrument yang dibutuhkan dan meminta data-data yang berkaitan dengan penelitian dapat berupa nilai-nilai siswa. Langkah-langkah dalam penelitian ini meliputi :

1) Menentukan dua kelas yang akan diteliti, dimana kedua kelas ini dipilih berdasarkan homogenitas dan normalitas kelasnya.

2) Menyusun instrumen mengajar yaitu soal yang akan digunakan dalam pre-test dan post-tes dimana soal antara kelas eksperimen dan kontrolnya sama dan juga menyusun RPP, dimana RPP yang dibuat ada dua jenis RPP pertama untuk kelas eksperimen menggunakan model pembelajaran Possing Problem dan untuk kelas kontrol menggunakan metode cermah.

3) Mengadakan pre-tes pada kedua kelas untuk mengetahui hasil belajar awal pada siswa sebelum diberi perlakuan.

4) Memberikan perlakuan pada kedua kelas, perlakuan diberikan sesuai dengan batas waktu yang telah ditentukan, perlakuannya berupa kelas eksperimen diajar dengan model pembelajaran Possing Problem dan kelas kontrol diajar dengan metode ceramah dimana materi yang diberikan sama.

5) Mengadakan post-test pada kelas eksperimen dan kelas kontrol setelah diberikan dua perlakuan yang berbeda untuk mengetahui hasil belajar siswa.

6) Menganalisis hasil penelitian setelah diperoleh nilai pre-test dan post-tes siswa.

7) Menguji hasil pre-test dan post-test dengan uji T-tes untuk mengetahuai apakah kelas yang diajar dengan model pembelajaran Possing Problem lebih tinggi hasil belajara Matematikanya dibanding siswa yang diajar dengan metode ceramah.

8) Kemudian diuji juga normalitasnya apakah kelas masih tetap berdistribusi normal atau tidak setelah diadakan penelitian, serta juga diuji homogenitasnya apakah kelas tetap homogen.

9) Membahas hasil yang diperoleh setelah penelitian selesai dilakukan.

10) Menarik kesimpulan dari hasil penelitian yang dilakukan.

B. Teknik Analisis Data

1) Uji Normalitas

Uji Normalitas dilakukan sebelum dan setelah penelitian untuk mengetahui kelas berdistribusi normal atau tidak. Uji Normalitas data dilakukan dengan rumus Chi-kuadrat, nantinya jika harga chi-kuadrat hitung yang diperoleh lebih besar daripada harga chi-kuadrat tabel maka data yang diperoleh tidak berdistribusi normal. Dan sebaliknya jika harga chi- 
kuadrat hitung lebih kecil dari harga chi-kuadrat tabel maka data yang diperoleh berdistribusi normal. Adapun rumus yang digunakan yaitu (Riduwan, 2010: 124):

$$
\chi^{2}=\sum \frac{\left(f_{0}-f_{h}\right)^{2}}{f_{h}}
$$

$$
\begin{aligned}
& \text { Keterangan: } \\
& \chi^{2}=\text { Nilai Chi-kuadrat } \\
& f_{h}=\text { Frekuensi yang diharapkan } \\
& f_{0}=\text { Frekuensi }
\end{aligned}
$$

2) Uji Homogenitas

Uji homogenitas dilakukan untuk menentukan sampel, karena sampel yang digunakan dalam penelitian harus homogen. Dalam penelitian ini uji homogenitas yang dipilih adalah membandingkan varians terbesar dengan varians terkecil. Adapun rumusnya adalah sebagai berikut:

$$
F_{\text {hitung }}=\frac{\text { Varians }_{\text {terbesar }}}{\text { Varians }_{\text {terkecil }}}
$$

Dengan kriteria pengujian sebagai berikut:

Jika $F_{\text {hitung }} \geq F_{\text {tabel }}$ berarti tidak Homogen dan jika $F_{\text {hitung }} \leq F_{\text {tabel }}$ berarti Homogen

C. Uji Hipotesis

Uji Hipotesis dalam penelitian ini digunakan rumus Separated Varians dan Polled Varians

$$
\begin{gathered}
t=\frac{\bar{x}_{1}-\bar{x}_{2}}{\sqrt{\left(\frac{s_{1}{ }^{2}}{n_{1}}+\frac{s_{2}{ }^{2}}{n_{2}}\right)}} \\
t=\frac{\overline{x_{1}}-\overline{x_{2}}}{\sqrt{\left(\frac{\left(n_{1}-1\right) s_{1}{ }^{2}+\left(n_{2}-1\right) s_{2}{ }^{2}}{n_{1}+n_{2}-2}\left(\frac{1}{n_{1}}+\frac{1}{n_{2}}\right)\right)}}
\end{gathered}
$$

Keterangan:

$$
\begin{array}{ll}
\overline{x_{1}} & =\text { Rata-rata sampel } 1 \\
\overline{x_{2}} & =\text { rata-rata sampel } 2 \\
\boldsymbol{s}_{1} & =\text { Simpangan baku sampel } 1 \\
\boldsymbol{s}_{2} & =\text { Simpangan baku sampel } 1 \\
\boldsymbol{s}_{1}{ }^{2} & =\text { Varians sampel } 1 \\
\boldsymbol{s}_{2}{ }^{2} & =\text { Varians sampel } 2 \\
\boldsymbol{r} & =\text { Korelasi antara dua sampel }
\end{array}
$$

Dalam menggunakan rumus di atas adapun ketentuannya adalah sebagai berikut:

1) Jika anggota sampel $\mathrm{n}_{1}=\mathrm{n}_{2}$ dan varians homogens $\left(\sigma_{1}{ }^{2}=\sigma_{2}{ }^{2}\right)$ maka dapat digunakan rumus t-test baik sparated maupun polled varians, untuk mengetahui t tabel digunakan $\mathrm{dk}$ yang besarnya $\mathrm{dk}=\mathrm{n}_{1}+\mathrm{n}_{2}-2$.

2) Jika anggota sampel $n_{1} \neq n_{2}$ dan varians homogens $\left(\sigma_{1}^{2}=\sigma_{2}{ }^{2}\right)$ maka dapat digunakan rumus t-test dengan polled varians, untuk mengetahui t tabel digunakan dk yang besarnya $\mathrm{dk}=\mathrm{n}_{1}+\mathrm{n}_{2}-2$. 
3) Jika anggota sampel $n_{1}=n_{2}$ dan varians homogens $\left(\sigma_{1}^{2} \neq \sigma_{2}^{2}\right)$ maka dapat digunakan rumus t-test baik sparated maupun polled varians, dengan derajat kebebasan dk yang besarnya $\mathrm{dk}=\mathrm{n}_{1}-1$ atau $\mathrm{dk}=\mathrm{n}_{2}-1$.

4) Jika anggota sampel $n_{1} \neq n_{2}$ dan varians tidak homogens $\left(\sigma_{1}^{2} \neq \sigma_{2}^{2}\right)$ maka dapat digunakan rumus t-test dengan sparated varians, harga $t$ sebagai penggati harga $t$ tabel dihitung dari selisih harga $\mathrm{t}$ tabel dengan $\mathrm{dk}=\mathrm{n}_{1}-1$ dan $\mathrm{dk}=\mathrm{n}_{2}-1$, dibagi dua dan kemudian ditambahkan dengan haga t terkecil.

\section{HASIL DAN PEMBAHASAN}

A. Hasil Analisis Data Uji Analisis Pendahuluan

1) Uji Normalitas

Tabel 1. Uji Normalitas Pre-test Kelas eksperimen dan kelas control

\begin{tabular}{ccccccc}
\hline No & \multicolumn{1}{c}{ Kelas } & $\mathrm{N}$ & $\alpha$ & $\chi^{2}{ }_{\text {hitung }}$ & $\chi^{2}$ tabel & Distribusi \\
\hline 1 & Kelas VIII A & 31 & 0.05 & -15.28 & 11.070 & Normal \\
\hline 2 & Kelas VIII B & 31 & 0.05 & -11.74 & 11.070 & Normal \\
\hline
\end{tabular}

Berdasarkan keterangan pada tabel uji normalitas nilai pre-tes kelas eksperimen hasilnya setelah disesuaikan dengan Ha dan Ho maka diperoleh kesimpulan bahwa Ho diterima dan Ha ditolak jadi dapat dikatakan bahwa kelas eksperimen berdistribusi normal begitu juga dengan kelas kontrol hasilnya setelah disesuaikan dengan Ha dan Ho maka diperoleh kesimpulan bahwa Ho diterima dan Ha ditolak jadi dapat dikatakan bahwa kelas kontrol juga berdistribusi normal.

Tabel 2. Uji Normalitas Post-test Kelas eksperimen dan kelas control

\begin{tabular}{ccccccc}
\hline No & Kelas & $\mathrm{N}$ & $\alpha$ & $\chi^{2}{ }_{\text {hitung }}$ & $\chi^{2}$ tabel & Distribusi \\
\hline 1 & Kelas VIII A & 31 & 0.05 & -408.73 & 11.070 & Normal \\
\hline 2 & Kelas VIII E & 31 & 0.05 & -20.14 & 11.070 & Normal \\
\hline
\end{tabular}

Berdasarkan keterangan pada tabel uji normalitas nilai post-test kelas eksperimen hasilnya setelah disesuaikan dengan Ha dan Ho maka diperoleh kesimpulan bahwa Ho diterima dan Ha ditolak jadi dapat dikatakan bahwa kelas eksperimen berdistribusi normal begitu juga dengan kelas kontrol hasilnya setelah disesuaikan dengan Ha dan Ho maka diperoleh kesimpulan bahwa Ho diterima dan Ha ditolak jadi dapat dikatakan bahwa kelas kontrol juga berdistribusi normal.

2) Uji Homogenitas

Tabel 3. Uji Homogenitas Pre-test Kelas eksperimen dan kelas control

\begin{tabular}{cccccccc}
\hline No & Kelas & $\mathrm{N}$ & Rata-Rata & $\mathrm{SD}$ & Varian & $\mathrm{F}_{\text {hitung }}$ & $\mathrm{F}_{\text {tabel }}$ \\
\hline 1 & Kelas VIII A & 31 & 23.806 & 11.522 & 132.761 & \multirow{2}{*}{1.083} & \multirow{2}{*}{1.84} \\
\hline 2 & Kelas VIII E & 31 & 24.065 & 11.072 & 122.596 & & \\
\hline
\end{tabular}

Berdasarkan keterangan pada tabel uji homogenitas nilai pre-tes kelas eksperimen dan kelas kontrol yang disesuaikan dengan Ha dan Ho maka diperoleh kesimpulan bahwa Ho diterima dan Ha ditolak jadi dapat dikatakan bahwa kelas eksperimen dan kelas kontrol adalah kelas yang homogen.

Tabel 4. Uji Homogenitas Post-test Kelas eksperimen dan kelas control

\begin{tabular}{cccccccc}
\hline No & Kelas & N & Rata-Rata & SD & Varian & $F_{\text {hitung }}$ & \multirow{2}{*}{$\mathrm{F}_{\text {tabel }}$} \\
\hline 1 & Kelas VIII E & 31 & 81.742 & 8.625 & 74.398 & \multirow{2}{*}{1.162} & \multirow{2}{*}{1.84} \\
\hline 2 & Kelas VIII A & 31 & 77.774 & 8.003 & 64.047 & & \\
\hline
\end{tabular}

Berdasarkan keterangan pada tabel uji homogenitas nilai post-test kelas eksperimen dan kelas kontrol yang disesuaikan dengan Ha dan Ho maka diperoleh kesimpulan bahwa Ho diterima dan Ha ditolak jadi dapat dikatakan bahwa kelas eksperimen dan kelas kontrol adalah kelas yang homogen. 
B. Uji Hipotesis Penelitian

Hipotesis nihil (Ho):

Tidak terdapat perbedaan hasil belajar matematika siswa kelas VIII SMP Negeri 3 Donggo semester ganjil pokok bahasan sistem persamaan linier tahun pelajaran 2021/2022 yang diajar menggunakan model pembelajaran possing problem berkelompok dan metode ceramah.

\section{Hipotesis alternatif (Ha):}

Terdapat perbedaan hasil belajar matematika siswa kelas VIII SMP Negeri 3 Donggo semester ganjil pokok bahasan sistem persamaan linier tahun pelajaran 2021/2022 yang diajar menggunakan model pembelajaran possing problem berkelompok dan metode ceramah

Berdasarkan hasil perhitungan diperoleh nilai $t_{\text {hitung }}$ adalah 1.877 dan $t_{\text {tabel }}$ adalah 1.671 untuk taraf signifikansi 5\%. Jika disesuaikan dengan hipotesis berdasarkan kriteria pengujian Ho

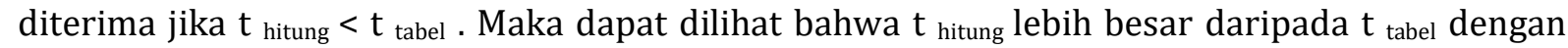
taraf signifikansi $5 \%$ sehingga dapat ditarik kesimpulan bahwa Ho ditolak dan Ha diterima. Hipotesisnya berbunyi "Terdapat perbedaan hasil belajar matematika siswa kelas VIII SMP Negeri 3 Donggo semester ganjil pokok bahasan sistem persamaan linier tahun pelajaran 2021/2022 yang diajar menggunakan model pembelajaran possing problem berkelompok dan metode ceramah".

\section{SIMPULAN DAN SARAN}

A. Simpulan

Kesimpulan dari penelitian ini yakni terdapat perbedaan hasil belajar matematika siswa kelas VIII SMP Negeri 3 Donggo semester ganjil pokok bahasan sistem persamaan linier tahun pelajaran 2021/2022 yang diajar menggunakan model pembelajaran possing problem berkelompok dan metode ceramah.

B. Saran

1) Dalam penelitian ini penelitian yang dilakukan adalah penelitian eksperimen biasa mungkin jika hendak dilakukan penelitian yang sejenis dapat dilakukan juga penelitian dengan pembagian prestasi siswa menjadi kelompok tinggi, sedang dan rendah, atau jenis kelamin atau yang lainnya.

2) Bagi peneliti lain yang ingin meneliti menggunakan Model Pembelajaran Possing Problem berkelompok diharapkan benar-benar menguasai tahapan pembelajarannya dan dapat menggunakan waktu seefektif dan seefisien mungkin

\section{DAFTAR RUJUKAN}

Arikunto, S. 2006. Dasar-Dasar Evaluasi Pendidikan. Jakarta: Bumi Aksara

Arikunto, S. 2008. Dasar-Dasar Evaluasi Pendidikan. Jakarta: Bumi Aksara

Cristiani, Janidya. 2011. Penerapan Pembelajaran Problem Possing Untuk Meningkatkan Aktifitas Dan Hasil Belajar Matematika siswa kelas VII SMPN 1 Lumajang Semester Ganjil Pokok Bahasan Aljabar Tahun Pelajaran 2010/2011. Jember: Universitas Muhammadiyah Jember

Hobri. 2009. Model-Model Pembelajaran Inovatif. Jember: CSS Jember

Jihad, Asep. 2008. Evaluasi Pembelajaran. Yogyakarta: Multi Pressindo

Jihad, Asep. 2008. Pengembangan Kurikulum Matematika. Yogyakarta: Multi Pressindo

Nasution. 1995. Berbagai Pendekatan dalam Proses Belajar dan Mengajar. Jakarta: Bumi Aksara

Nuharini. 2008. Matematika Konsep dan Aplikasinya untuk Kelas VIII SMP dan MT. Surabaya: Pusat Perbukuan

Pribadi. 2009. Model Desain Sistem Pembelajaran. Jakarta: Dian Rakyat

Riduwan. 2010. Belajar Mudah Penelitian. Bandung: Alfabata 
Roestiyah. 2006. Strategi Belajar Mengajar. Jakarta: Rineka Cipta

Santi, Eka Mulya. 2011. Penerapan Pembelajaran Possing Problem Untuk Meningkatkan Aktivitas dan Hasil Belajar Siswa Kelas VII SMPN 2 Bondowoso Semester Genap Pokok Aritmetika Sosial Tahun Pelajaran 2010/2011. Jember: Universitas Muhammadiyah Jember

Slavin, Robert. 2010. Cooperative Learning. Nusa Media: Bandung

Sudirman. 1991. Ilmu Pendidikan. Bandung: Remaja Rosdakarya

Sudjana. 2010. Dasar-Dasar Proses Belajar Mengajar. Bandung: Sinar Baru Algesindo

Sugiyono. 2007. Statistik Untuk Penelitian. Bandung: Alfabata

Suprijono, Agus. 2010. Cooperative Learning. Yogyakarta: Pustaka Pelajar

Suryosubroto, 1997. Proses Belajar Mengajar Di Sekolah. Jakarta: Rineka Cipta

Thobroni, Muhammad. 2011. Belajar dan Pembelajaran. Jakarta: Rineka Cipta 